\title{
The Treasurer Reports
}

The Treasurer, Ph. Choquard, in summarising the Society's income and expenditure for 1992 at the Executive Committee meeting on 6 February, reported that the accumulated deficit is considerably reduced. Its elimination has been the target since the 1990 Council in Uppsala, testifying to the Treasurer's perseverance in tackling a difficult job in difficult times. Based on an estimated surplus of 66.7 kSFR for the year (see Table 1), the accumulated deficit now stands at $15.4 \mathrm{kSFR}$, exactly $10 \%$ of the level at the end of 1990 before the vigorous measures to put things right took effect.

\section{Satisfactory}

Fee income from the individual membership categories (Art. 4a, 4c and 4d) of 187.7 kSFR was virtually unchanged from the 1991 level of $188.8 \mathrm{kSFR}$, indicating that individuals still value membership in EPS in spite of the economic climate. This income was below budget as significant numbers of members often defer fee payment for a year and then pay for two. In general, therefore, the increase in the unit fee in 1992 from SFR 12.- to 13.5 was accompanied by only a very small reduction in membership. On the national society side, east and central Europe are obviously having problems in paying full fees. The budgeted income from societies had been set at $47.3 \mathrm{kSFR}$ less than the amount invoiced on the basis of announced memberships. This estimate turned out to be very accurate; it was only partially offset by a total of $12.1 \mathrm{kSFR}$ in donations following appeals by the President and the Treasurer. Fees from Associates were maintained at the budgeted level of 210 kSFR - about 6 kSFR higher than the sum received in 1991 - so the recent momentum in attracting new Associates has been maintained. Finally, there were donations totalling $8 \mathrm{kSFR}$ from the Ecole Polytechnique Fédérale de Lausanne and from W. Buckel.

Regarding other items of income: bulk sales of Europhysics News were slightly below budget as extra sales of the only special issue in the year were disappointing. Advertising income, however, was maintained in spite of the economic climate. A better than expected profit from Europhysics Letters and income from the European Journal of Phy. sics gave a total income that was about 20 kSFR more than budgeted.

On the expenditure side, for salaries other than those ascribed to Europhysics News, Council accepted a $16.6 \mathrm{kSFR}$ increase relative to the 1991 level of 266.4 kSFR. They in fact increased by $40.6 \mathrm{kSFR}$, in the main because a bookkeeper was hired so that the Society could be audited in March 1993 for the first time in three years. Secretariat expenses of 180 kSFR corresponded to an increase in 1992 of 39 kSFR relative to 1991; this was 13 kSFR below the budgeted increase as less was spent on promotion and equipment. It should be pointed out that the Society had to absorb a fairly large increase of $24.5 \mathrm{kSFR}(28 \%)$ for rent, mailing and telephone charges in 1992.
Some 5 kSFR less than the sum agreed by Council was spent on the costs of travel and meetings after $4.5 \mathrm{kSFR}$ had been specially set aside for east-west events.

\section{Cautious}

Turning to the future, the Executive Committee agreed to propose to Council a cautious budget for 1993 that envisages:

- Fees: a reduced income from membership fees. Adjustment has to be made for the decrease in the fee for $4 \mathrm{a}$ ) members from SFR 162.- to SFR 108.- decided by Council last year. It is estimated that $4 \mathrm{a}$ ) income will drop from $16.2 \mathrm{kSFR}$ in 1992 to $10.8 \mathrm{kSFR}$ in 1993. The Treasurer is also taking a conservative line regarding contributions from the Associates.

The Executive Committee has thought about the fairest and most sensible way to handle fees from new societies in east and central Europe which have joined recently, or will join in the future. It was decided in November to propose as a guideline to new members that the first year's fee should be at least $20 \%$ of the full amount based on the number of members declared, and should increase by $10 \%$ of the full amount each year. Every effort will meanwhile be made to find sponsors to cover the balance of the fees due. In making what he feels is a realistic appreciation of the situation, the Treasurer has kept 4b) income for 1993 at the 1992 level. The total of donations to cover unpaid

\begin{tabular}{|c|c|c|}
\hline INCOME & $\begin{array}{c}\text { Budget accepted } \\
\text { by Council }\end{array}$ & $\begin{array}{c}\text { New } \\
\text { estimate }\end{array}$ \\
\hline \multicolumn{3}{|l|}{ Membership fees } \\
\hline Art. 4a) & 21060 & 16200 \\
\hline Art. 4c) & 175500 & 162000 \\
\hline Art. 4d) & 12150 & 9450 \\
\hline Art. 4b) & 356000 & 369056 \\
\hline Associate Members & 210000 & 210000 \\
\hline Gifts and donations & 8000 & 8000 \\
\hline sub-total & $(783210)$ & (774 706) \\
\hline \multicolumn{3}{|l|}{ Europhysics News } \\
\hline Bulk subscriptions & 50000 & 40000 \\
\hline Library subscriptions & 13500 & 13500 \\
\hline Advertisements & 45000 & 45000 \\
\hline sub-total & (108 500) & $(98500)$ \\
\hline \multicolumn{3}{|l|}{ Other } \\
\hline Europhys. Conf. Abs. & 20000 & 20000 \\
\hline Various sales & 10000 & 5000 \\
\hline European J. of Physics & - & 35000 \\
\hline Europhysics Lett. & 5000 & 12000 \\
\hline sub-total & (35 000) & (72 000) \\
\hline Total income & 926710 & 945206 \\
\hline
\end{tabular}

Table 1 - EPS income and expenditure (in SFR) for 1992: as accepted by Council in March 1992 and the latest estimates submitted by the Treasurer to the Executive Committee in $\mathrm{Fe}$ bruary 1993. fees has been budgeted at 22 kSFR, corresponding to the total sum which has already been donated by the UK, German, and Swiss societies.

- Europhysics News: the bulletin is being called upon to obtain $10 \mathrm{kSFR}$ of extra sales from special issues while maintaining other sources of income. At the same time, the nurnber of issues published each year has been reduced to 10 . While it is agreed that the number of pages can increase if sales permit from 20 to 24 pages per issue, the printing and distribution cost is reduced by a total of 20 kSFR whatever the number of pages finally printed. The effect of this change is that non-salary costs ascribed to News will have risen by only 6 kSFR since 1991 , i.e., by $1.9 \%$ p.a., significantly less than the average rate of inflation for the period $(5.2 \%$ p.a.). The increase is entirely accounted for by larger distribution costs, which includes all EPS communications to members. - Salaries: salaries other than those ascribed to News are foreseen to increase to 370 kSFR. This represents a $63 \mathrm{kSFR}$ increase relative to the 1992 level of $307 \mathrm{kSFR}$ to permit G. Thomas, the Executive Secretary, to be once again based full-time in Geneva instead of Budapest from 1 January. These salaries had dropped to $266.4 \mathrm{kSFR}$ in 1991 and $283 \mathrm{kSFR}$ in 1992 with the transfer of the Executive Secretary and some activities to Budapest; they are now back to slightly below the level of 390 kSFR budgeted for back in 1990, implying that most increases due to inflation and new initiatives have been contained by moving activities.

- Secretariat expenses: it is believed that expenses can be stabilised at close to the 1992 level by trimming the various items to compensate for further rent increases.

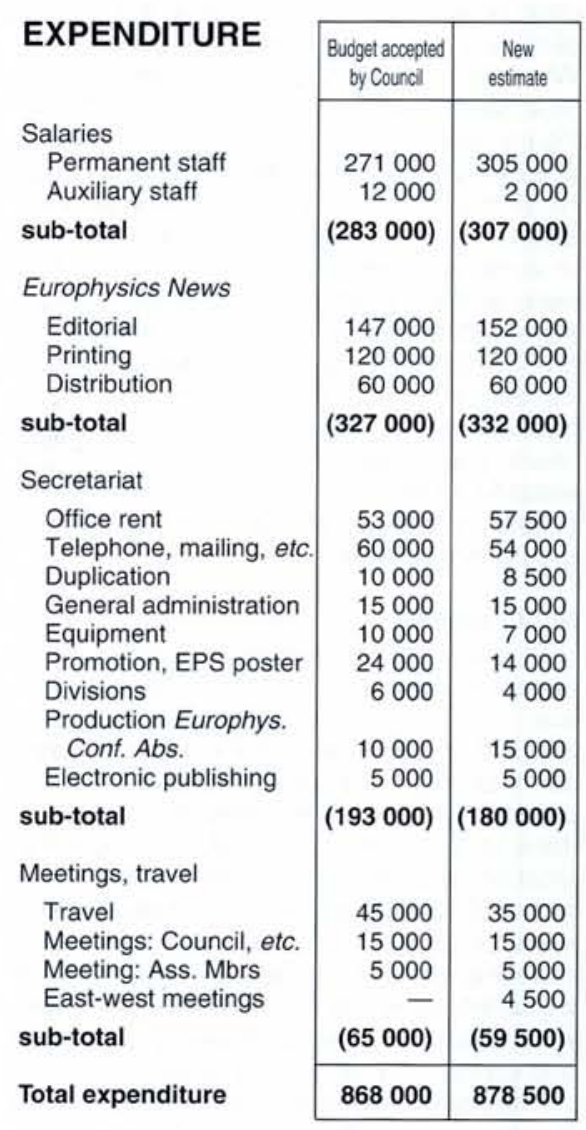


Table 2 - Summary of EPS finances for 1991-1993 (in Swiss francs)

\begin{tabular}{|c|c|c|c|}
\hline Item & $\begin{array}{c}1991 \\
\text { final estimate }\end{array}$ & $\begin{array}{c}1992 \\
\text { final estimate }\end{array}$ & $\begin{array}{c}1993 \\
\text { proposed }\end{array}$ \\
\hline $\begin{array}{l}\text { Total income } \\
\text { Total expenditure } \\
\text { Surplus }\end{array}$ & $\begin{array}{l}866060 \\
757600 \\
108460\end{array}$ & $\begin{array}{r}945206 \\
878500 \\
66706\end{array}$ & $\begin{array}{r}930750 \\
921000 \\
9750\end{array}$ \\
\hline Accumulated deficit & 82080 & 15374 & 5624 \\
\hline
\end{tabular}

- Travel and special activities: as the Executive-Secretary will be travelling less there is some reduction in travel expenses. Furthermore, the French Commissariat à l'Energie Atomique has agreed to pay the equivalent of $7 \mathrm{kSFR}$ towards the costs of the Council meeting in Nice. This contribution is intended to compensate for Associate membership fees which were recently overlooked while the organization was restructuring. bility) are slated to receive $12 \mathrm{kSFR}$ in 1993.

Summarising, Table 2 shows that the ExeSpecial activities (education, east-west, mo- cutive proposes a slight fall off in total income, with a $42.5 \mathrm{kSFR}$ increase in expenditure, relative to the estimates for 1992 . The target is a modest surplus of $9.8 \mathrm{kSFR}$, sufficient to essentially eliminate the accumulated deficit in this the 25th anniversary year of EPS. Our Treasurer feels that with good luck and much goodwill, he will have accomplished the mission he set himself. He leaves a sound ship in the very.capable hands of his successor, Professor Hans Beck from the University of Neuchâtel in Switzerland, who will be proposed as the next Treasurer.

\section{Letter to the Editor}

\section{CERN Membership}

I refer to the summary you wrote in Europhysics News of the EPS Associate Members Annual Meeting "The Rôle of Large-Scale Facilities" in Grenoble on 10 November 1992.

In the section Particle Physics you state: "Cooperation agreements have been set up with Albania, Romania and Bulgaria (essentially countries that will never become full members)". This statement is incorrect and does not reflect what I said at the meeting. Membership of CERN is open to all countries. The application for membership of the individual countries depends on the level of highenergy physics, and their willingness to join CERN. Also the financial possibilities have to be taken into account, although CERN has made special arrangements in the case of Poland, Czechoslovakia and Hungary in the form of a transition period before reaching full contribution levels.

Walter Hoogland

Director of Research, CERN, Geneva

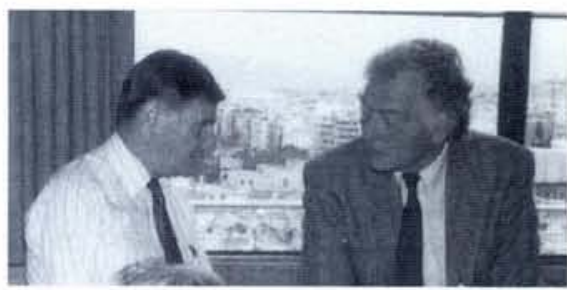
and administration

- A non-refundable application fee is paid to a RMC and a periodically renewable registration fee is paid to the Register Commission.

\section{Next Steps}

The Working Group recommends that the next steps should be to:

- Expand the membership of the Working Group with a view to it becoming the first Register Commission;

- Propose terms of reference for the Commission to the Executive Committee;

- Eventually make a call for proposals for Regional Monitoring Committees.

There are obviously many details to be worked out, but Derek Jefferies, the Group's Chairman, is confident that the proposed scheme is both realistic and sound. It will also be flexible enough to meet the needs of following calls for proposals for their creation
$D . R$. Jefferies (on the left) and C. van der Leun of the professional qualifications working group. Seen talking in Athens at the 1992 Council, they have done most of the work involved in preparing the report and proposals for the 1993 Council in Nice.

the many physicists who seek professional recognition in addition to an academic qualification. Decentralization through the regional committees means the scheme would be open to all at the start as the Register Commission would welcome proposals for several committees. Meanwhile, a high standard and the all-important uniformity throughout Europe would be ensured by making the Commission responsible for monitoring the scheme, and for appointments to the regional committees. exercise a profession).

- The qualification is open to all European physicists (with reduced rates for members of EPS and/or its national member societies). - The appointment by EPS Council of a European Physicists Register Commission, reporting to Council, responsible for admissions and removals to and from the Register, and for monitoring standards.

- The appointment by the EPS Executive Committee upon the Commission's recommendation, of Regional Monitoring Committees (RMC's) composed of a national society (or societies where there is a some commonality in education). Other national organizations may also be represented in some form. Representatives of EPS member societies are in the majority.

- Applications are submitted to a RMC which makes recommendations to the Commission: the RMC's handle all communications with applicants.

- The RMC's operate through agents chosen

\section{ATOMIC \& MOLECULAR PHYSICS DIVISION \\ Electronic \& Atomic Collisions Section REELECTION OF BOARD}

The Electronic and Atomic Collisions Section of AMPD will reelect all of its Board during the 18th International Conference on the Physics of Electronic and Atomic Collisions (ICPEAC) at Aarhus, Denmark, on Friday, 24 July 1993 (12.30 h). The EACS Board consists of six elected members, serving for three years, plus up to six co-opted members. The previous board members, who have all served for the maximum period, are listed in Europhysics News 23 (1992) 130.

Individual Ordinary Members of EPS, who are Section members, and National Societies (Cat. 4b) are invited to make nominations; those made by IOM's should be endorsed by at least six members. Nominations should be sent to the AMPD chair $(\mathrm{H}$. Hotop, Fachbereich Physik, Univ. Kaiserslautern, W-6750 Kaiserslautern; fax: $+49-631-2053300$ ) and arrive by the end of May, 1993.

The 18th ICPEAC will be held on 21-27 July 1993, at the Concert Hall in Aarhus. For information write to ICPEAC XVIII Secretary, Institute of Physics and Astronomy, Aarhus University, DK-8000 Aarhus C (fax: +45-86-12 0740 ). 